\author{
Daniel Maliński \\ Katedra Logiki i Metodologii Nauk \\ Uniwersytet Łódzki \\ malinski.daniel@gmail.com
}

\title{
METAFORA W NOWEJ RETORYCE CHAIMA PERELMANA I LOGICE NIEFORMALNEJ DANIELA H. COHENA
}

\begin{abstract}
ABSTRAKT
W niniejszym artykule zestawiono propozycje dwóch myślicieli - Chaima Perelmana i Daniela H. Cohena, którzy w swojej refleksji z pogranicza retoryki, teorii argumentacji i filozofii języka zdecydowali się spojrzeć na metaforę jako na narzędzie argumentacyjne. Artykuł został podzielony na dwie główne części, z których część pierwsza traktuje o nowej retoryce Chaima Perelmana oraz roli jaką odgrywa w niej metafora, zaś część druga traktuje o logice nieformalnej Daniela H. Cohena i proponowanym przez niego spojrzeniu na metaforę.
\end{abstract}

\section{SŁOWA KLUCZOWE}

Argumentacja, metafora, nowa retoryka, logika nieformalna, teoria metafory.

\section{SŁOWO WSTĘPNE}

Teoria argumentacji to obecnie jeden z najpopularniejszych obszarów dociekań z pogranicza nauk humanistycznych i społecznych. W jej skład wchodzą takie dyscypliny jak np. retoryka, logika czy dialektyka (nie tylko w ich wersjach antycznych, ale również we współczesnych odmianach), językoznawstwo, psychologia, Trudno zatem mówić o jednej teorii argumentacji, czy też jednym, wspólnym dla tych dyscyplin przedmiocie badań. Jeżeli zaś interdyscyplinarne badania $\mathrm{w}$ zakresie teorii argumentacji potraktujemy jako część dociekań z zakresu badań nad komunikacją sprawa skomplikuje się jeszcze bardziej.

Mając świadomość złożoności problemu zdecydowałem się ograniczyć do krótkiego przedstawienia koncepcji dwóch myślicieli, których koncepcje 
lokują się w obszarze retoryki i logiki. Są to koncepcja nowej retoryki Chaima Perelmana oraz logika nieformalna Daniela H. Cohena.

Jeżeli zdecydujemy się odwołać do klasycznego podziału na logos, ethos i pathos, który zaproponował Arystoteles w Retoryce, to obydwie wymienione propozycje wpisują się w koncepcje skoncentrowane na problemie logosu, ale jednocześnie przywiązujące istotną wagę do ethosu mówcy. To właśnie, a także kwestia związana $\mathrm{z}$ wykorzystaniem metafory w toku argumentacji, stało się podstawą do zestawienia ze sobą tych dwóch koncepcji. Czynnikiem pośrednim odgrywającym rolę podczas wyboru autorów był związek proponowanych przez nich teorii z filozofią amerykańskiego pragmatyzmu, który w obydwu przypadkach odegrał istotną rolę w poglądach filozofów.

\section{METAFORA I ARGUMENTACJA WSPÓŁCZEŚNIE}

Krzysztof Szymanek podaje w Sztuce argumentacji - stowniku terminologicznym taką oto definicję metafory:

Metafora (gr. $\mu \varepsilon \tau \alpha \varphi \rho \rho \alpha ́)$, metaphora - przeniesienie; łac. translatio) ret. przenośnia, podstawowy i najważniejszy z tropów, zmiana znaczenia użytych w wyrażeniu słów; uzyskana na skutek ich specyficznego, znaczeniowego zestawienia (...) [Szymanek 2001, s. 197].

Choć sama definicja może wydawać się mało problematyczna, to jednak jej aplikacja do analizy konkretnych argumentów wielokrotnie może nastręczyć problemów. To właśnie z problemem zastosowania metafory w argumentacji próbowali zmierzyć się Perelman i Cohen, choć należy odnotować, iż nie są oni ani najwybitniejszymi, ani też pierwszymi współczesnymi filozofami, którzy próbowali przyjrzeć się temu zagadnieniu.

Do połowy XX wieku i pojawienia się książek Models and Metaphors Maxa Blacka oraz Metaphors We Live By George'a Lakoffa i Marka Johnsona metafora pozostawała poza głównym nurtem zainteresowań badaczy zajmujących się filozofią analityczną oraz logiką praktyczną (zwaną również nieformalną). Jednak wraz z rozwojem filozofii języka i teorii argumentacji stopniowo zaczęło ukazywać się coraz więcej takich publikacji, a z czasem metafora użyta $\mathrm{w}$ argumentacji filozoficznej przestała być traktowana tylko jako środek stylistyczny posiadający jedynie walory retoryczne. Jednak mimo rozwoju badań nad teorią metafory nadal dostrzegalny jest deficyt badań z obszaru teorii argumentacji, które koncentrowałyby się na zagadnieniu metafory w kontekście filozoficznym. 
W odróżnieniu od tzw. tradycji postmodernistycznej, w nowej retoryce oraz logice nieformalnej trudno szukać wielkich monografii dotyczących metafory. Myśliciele związani z tymi dwiema tradycjami z reguły bardziej koncentrowali się na błędach pojawiających się w rozumowaniach, niż np. na epistemicznych walorach metafor.

\section{METAFORA W NOWEJ RETORYCE CHAIMA PERELMANA}

Wiek XX przyniósł znaczący wzrost zainteresowania zagadnieniem metafory, doprowadzając tym samym do narodzin całego szeregu publikacji, które dziś można określać mianem teorii metafory. Wśród rozmaitych koncepcji z zakresu filozofii języka, logiki czy retoryki szczególne miejsce zajmuje szkoła nowej retoryki, którą zainicjował belgijski filozof polskiego pochodzenia, Chaim Perelman. Głównymi obszarami refleksji Perelmana były logika i filozofia prawa, co jest widoczne w proponowanej przez niego teorii argumentacji, w której etyka mówcy odgrywa istotną rolę w konstruowaniu argumentacji, a pojęcie prawdy zostało zastąpione pojęciem przekonania.

Jak zauważa Ryszard Kleszcz, w twórczości Perelmana wyraźne są dwa okresy [por. Kleszcz 2005]. Pierwszy okres należy do bardziej teoretycznego i dominuje w nim refleksja z obszarów logiki i teorii poznania. Drugi okres, który rozpoczyna się po II wojnie światowej, można określić bardziej praktycznym, gdyż Perelman koncentruje się $\mathrm{w}$ nim na zagadnieniach $\mathrm{z}$ zakresu etyki i teorii argumentacji. To właśnie $\mathrm{w}$ drugim okresie powstaje koncepcja nowej retoryki.

U jej założeń leży przekonanie Perelmana, że filozofia może mieć przełożenie na praktykę, a filozofowie mogą się wiele nauczyć analizując argumentację prawniczą. Jednocześnie jest on przekonany, iż poznanie filozoficzne jest nieredukowalne do poznanie naukowego, a tym samym wymaga pewnych modyfikacji w obszarze dowodzenia i argumentacji.

Zaproponowany przez Perelmana projekt nowej retoryki spotkał się w latach 50. XX wieku z dużym zainteresowaniem, gdyż starał się powrócić do problemu perswazji językowej $\mathrm{w}$ ramach debaty publicznej. Był to okres dynamicznego rozwoju wszelkich badań leżących u podłoża współczesnych nauk o komunikacji i perswazji.

Stając w opozycji do powszechnego poglądu głoszącego, że retoryka jest sztuką krasomówstwa, którego jedynym celem jest perswazja językowa wywierana na audytorium bez względu na merytoryczną wartość przekazu, Perelman starał się sięgnąc do tej tradycji filozoficznej, która kładła nacisk na element etyczny. W ten sposób jego koncepcja jest bliższa antycznej dialektyce Arystotelesa, niż Schopenhauerowskiej erystyce. Jego zamysłem było 
restytuowanie retoryki rozumianej jako narzędzie skutecznej i racjonalnej perswazji, co w owym czasie wydawało się kwestią zapomnianą.

Michel Meyer, historyk retoryki oraz uczeń Perelmana, zauważa, że wiek XX przyniósł cały szereg nowych koncepcji dotyczących roli retoryki w debacie publicznej [por. Meyer 2010, s. 255]. Pisze o „zwrocie retorycznym”, którego reprezentantami mieliby być Jurgen Hebermas, Chaim Perelman, Umberto Eco i Hans Georg Gadamer. W innym miejscu Meyer stwierdza, że są oni reprezentantami „wielkiej rewolucji retoryki” [tamże, s. 264]. Trudno zaprzeczyć, że badania nad perswazją językową rozwijające się niezwykle dynamicznie po II wojnie światowej, miały na celu wyjaśnienie jak można prowadzić debatę publiczną $w$ społeczeństwach demokratycznych, aby stosować możliwie najskuteczniejsze techniki przy zachowaniu dopuszczalnych standardów. Prace Perelmana wpisują się tę tendencję, starając się wskazać drogę, którą powinna podążać teoria argumentacji zorientowanej na prawodawstwo i debatę publiczną.

Traite de l'argumentation, czyli opus magnum Perelmana zawiera jego najobszerniejszy wykład na temat technik argumentacyjnych. To tam można znaleźć definicje retoryki, która głosi, iż „przedmiotem tej teorii jest badanie technik dyskursywnych pozwalających wywołać lub zwiększyć akces umysłów do tez przedstawianych za ich zgodą [por. Perelman i Olbrechts-Tyteca 1958, cytuję za Mayer 2010, s. 266]. Zwłaszcza ostatni człon tej definicji będzie istotny dla wszystkich myślicieli związanych z nową retoryką. Nie chodzi bowiem o perswazję mającą na siłę przekonać odbiorców do tez głoszonych przez nadawcę komunikatu, lecz do przekonania ich w oparciu o twierdzenia racjonalne.

Nowa retoryka, którą postuluje Perelman, nie jest sztuką perswazji opierającą się na patosie, lecz techniką wyrazu literackiego. Jednak jako technika argumentacyjna nie ma na celu posługiwania się figurami stylistycznymi w celach estetycznych, lecz w celach praktycznych. Perswazja jest dla Perelmana kwestią tego, czy dane argumenty są oparte na racjonalnych przesłankach i są przedstawione w sposób przystępny dla audytorium. Obydwa warunki są warunkami sine qua non rzetelnej argumentacji.

Jego zdaniem w filozofii nie da się korzystać z technik dowodzenia tak rozumianych, jak ma to miejsce $w$ naukach dedukcyjnych. Uważa on, że filozofia jest domeną argumentacji, a nie dowodzenia, co pociąga za sobą istotne konsekwencje. Poniżej przedstawiam część z nich.

1. Ponieważ odwołujemy się do argumentacji, a nie do dowodu, nie możemy mówić o występowaniu sprzeczności, lecz o zaistnieniu niezgodności;

2. Argumentacja filozoficzna jest niekonkluzywna; 
3. Nie możemy mówić o pojęciu prawdy, lecz o prawdopodobieństwie;

4. Debata filozoficzna ma charakter deliberacyjny.

W tym miejscu warto nadmienić, że Michel Meyer uważa, iż nowa retoryka Perelmana nie jest tak naprawdę retoryką, lecz argumentacją, gdyż nie koncentruje się ona na walorach stylistycznych mowy, ale na zagadnieniach zasadności użytych argumentów. Stosując klasyczny podział na ethos, logos i pathos oraz odróżniając retorykę rozumianą jako sztukę stylu od argumentacji, Meyer lokuje nową retorykę w obszarze argumentacji skoncentrowanej na logosie [Meyer 2010, s. 260]. Za takim podejściem przemawia fakt, iż Perelman w znikomym stopniu zdaje się interesować retoryką stylu. Sam definiuje nową retorykę w następujący sposób:

\footnotetext{
Nowa retoryka, jak widzieliśmy, jest nauką o technikach dyskursywnych, które mają na celu wywołanie lub wzmocnienie poparcia twierdzeń przedstawianych pewnemu audytorium [Perelman 1984, s. 156].
}

Definicja ta jest bliska antycznemu rozumieniu retoryki, które przypisujemy Arystotelesowi i taki też był cel przyświecający jej autorowi. Trzeba w tym miejscu jeszcze raz podkreślić, że teorię argumentacji postrzega on jako teorię skoncentrowaną na kwestii publicznego sporu, gdzie zadaniem jest racjonalne przekonywanie audytorium do swoich poglądów. Perelman daleki jest od omawiania kwestii etycznych, mniej lub bardziej słusznie, przypisywanych sofistom, które zwalniałyby mówcę od odpowiedzialności za głoszone poglądy i przerzucałyby ciężar odpowiedzialności na audytorium i jego umiejętności krytycznego myślenia.

\section{METAFORA W NOWEJ RETORYCE CHAIMA PERELMANA}

Perelman przekonuje, że w filozoficznej argumentacji stosowanie metafory jest uzasadnione, ponieważ poznanie filozoficzne nie jest redukowalne do poznania naukowego, któremu należy przypisywać możliwie jednoznaczne argumenty. Odrzuca on pogląd powszechny wśród zwolenników pozytywizmu logicznego, który głosił równoznaczność wyrażeń metaforycznych z bełkotem w filozofii. Niestety w swojej twórczości Perelman nie poświęca zbyt wiele miejsca zagadnieniu metafory, traktując ją jako swoistą odmianę argumentu $\mathrm{z}$ analogii.

Niemniej dostrzega on potrzebę użycia metafory w debacie publicznej, naukowej i filozoficznej. Jego zdaniem w procesie argumentacji metafory odgrywają istotną rolę tam, gdzie wyrażenia dosłowne nie są w stanie wyrazić subtelności poznania filozoficznego lub danego zagadnienia. 
Drugim istotnym powodem, dla którego filozof może, a czasem nawet powinien posłużyć się metaforą jest jej wartość heurystyczna. Podobnie jak w przypadku argumentu z analogii odgrywa ona rolę pomocniczą. Ma na celu uczynienie pewnego nieznanego zjawiska lub problemu bardziej przystępnym dla danego audytorium.

Zarówno wartość poznawcza, jak i heurystyczna metafor stosowanych w filozofii są ze sobą ściśle związane. O ile bowiem w przypadku wypowiedzi sądowej lub prawniczej celem jest głównie przybliżenie pewnego zjawiska oraz perswazja językowa, o tyle w przypadku filozofii zastosowanie metafory powinno być ściśle ograniczone ze względu na niedostatki dostępnych wypowiedzi dosłownych. Z taką sytuacją mamy najczęściej do czynienia w przypadku tez z obszaru metafizyki.

Stosowanie metafor $\mathrm{w}$ ramach argumentacji jest obarczone u Perelmana ważnym zastrzeżeniem, podobnym do tego, które obowiązuje w przypadku użycia analogii. Otóż istotnym jest, aby posługując się metaforą pamiętać, że działamy w warunkach przesłanek niepewnych. Dlatego należy doprecyzować, co leży u podłoża użycia danej metafory. Zastosowanie metafory w ramach filozoficznej argumentacji nie może odbywać się w sposób dowolny, jak ma to miejsce np. w poezji. Filozof powinien starać się prezentować swoje stanowisko w sposób możliwie precyzyjny, tylko w określonych okolicznościach sięgając po wyrażenia metaforyczne, nawet jeżeli głosi tezy z obszaru metafizyki czy też filozofii religii.

Należy przy tym uwzględniać ograniczenia związane $\mathrm{z}$ formą wypowiedzi (np. czy jest to referat przed szerokim gronem odbiorców, czy też artykuł w czasopiśmie branżowym). Kontekst wypowiedzi może nakładać na nas obowiązek wyjaśnienia zastosowanej metafory. Widać wyraźnie, że problem metafory zostaje zredukowany do warunków użycia analogii, a sama metafora jest tylko odmianą analogii.

Nowa retoryka ma na celu pokonanie ograniczeń, jakie nakładał na filozoficzną argumentację pozytywizm logiczny. Perelman przeciwstawia się koncepcji Rudolfa Carnapa, dostrzegając w wieloznaczności wypowiedzi języka naturalnego siłę poznawczo-eksplanacyjną. Redukcjonizm, który proponuje można nazwać słabym, gdyż wyrażenia metaforyczne są dla niego nie tylko dopuszczalne w ramach filozofii, ale momentami wręcz niezbędne. Dzieje się tak nie dlatego, że metafory dają nam np. poznanie irracjonalne, lecz dlatego iż pozwalają one na rozsądne przedstawienie problemu i jego rozwiązania, których za pomocą wyrażeń dosłownych przedstawić nie możemy. 
W tym miejscu warto poczynić uwagę, że Perelman nie antycypuje postmodernistycznego podejścia do języka, które głosi, że wszystko jest metaforą ${ }^{1}$. Widać wyraźnie, że inspirowany filozoficznym pragmatyzmem poszukuje środkowej drogi, a wszelkie skrajności stara się rozpatrywać z perspektywy uniwersalnego rozumu [Perelman 1984, s. 166].

Perelman nie przytacza zbyt wielu przykładów metafor, jednym z nielicznych jakie podaje jest ,niewidzialna ręka” Adama Smitha. Ma ona pokazywać ukrytą harmonię zachodząca między interesem indywidualnym i wspólnotowym w obszarze gospodarki. Ta metafora jest tak silnie zakorzeniona w naszej kulturze, że dziś rozumiana bywa w sposób niemal dosłowny. Jest to o tyle istotne, że pokazuje jak bardzo pewne wyrażenia stając się bliskie użytkownikom danego języka przestają być postrzegane jako problematyczne. Belgijski filozof nie chce dostrzec w tej, ani w innych metaforach, siły inicjującej debatę i ogranicza się do postrzegania jej przez pryzmat zjednywania sobie audytorium.

Należy w tym miejscu pamiętać, że Perelman nie tworzy rozbudowanej teorii metafory. W jego pracy istotniejszą rolę odgrywają inne figury, które znacznie częściej od metafor, pełnią rolę argumentacyjną. Zajmuje go argumentacja jako rozszerzona forma Rozumu oraz racjonalności i dlatego metafora, jako niestandardowe narzędzie argumentacji, jest na obrzeżach jego teorii.

Nie należy przy tym nie doceniać roli metafory w argumentacji, trzeba jednak pamiętać, że jej użycie jest dopuszczalne pod pewnymi warunkami. $Z$ całą pewnością nie deprecjonuje on roli metafory i nie ogranicza jej jedynie do funkcji perswazyjnej. Perelman dostrzega nie tylko jej funkcję stylistyczną lub eksplanacyjną, ale również pewną formę argumentu. W niektórych swoich publikacjach zdawał się traktować metaforę jako swoistą, skondensowaną analogię. Jako taka jest połączeniem tematu i phoros ${ }^{2}$.

O ile analogia musi zachodzić pod pewnymi względami, a na mówcy ciąży obowiązek wskazania zasadności jej zastosowania, o tyle w przypadku wyrażeń metaforycznych powody, które stoją za jej użyciem mogą być nieco mniej precyzyjne.

Stanowisko Perelmana jest o tyle ciekawe we współczesnym świecie, że w kręgu amerykańskiej filozofii prawa coraz częściej zwraca się uwagę na rolę metafor w argumentacji sądowej i prawniczej. Logika prawnicza w XXI wieku

\footnotetext{
1 Stanowisko takie można przypisać np. Jacquesowi Derridzie, a wśród wcześniejszych myślicieli Fryderykowi Nietzschemu.

${ }^{2}$ Dla Perelmana temat jest pierwszym członem analogii, a phoros drugim.
} 
stara się patrzeć na metaforę nie tylko jako na erystyczno-estetyczny zabieg stylistyczny, ale również jako racjonalne narzędzie przekonywania ${ }^{3}$.

W tej kwestii Perelman różni się np. od Johna Stuarta Milla, który postrzegał metaforę tylko jako jeden z tropów językowych, ale nie przypisywał jej wartości dowodu, czy też argumentu.

Metafora rozumiana jako skondensowana analogia budzi skojarzenia z oraz powszechniej spotykany zwrotem „skrót myślowy”. Choć samo to sformułowanie budzi kontrowersje wśród językoznawców i filozofów języka, to jednak w wielu wypadkach może dobrze oddawać to, jaką rolę odgrywa metafora $\mathrm{w}$ argumentacji.

Przy czym istotne jest, aby już samo sformułowanie „skrót myślowy” rozumieć niedosłownie, lecz metaforycznie. Wydaje się, że może ono naprowadzać odbiorcę na to, czym jest metafora potraktowana jako jeden $\mathrm{z}$ argumentów. Nie jest ona bowiem argumentem dosłownym. Oczywistym jest, że zastosowanie metafor $\mathrm{w}$ toku argumentacji może być zabiegiem ryzykownym, gdyż są one podatne na rozmaite interpretacje. Dotyczy to zwłaszcza metafor nowatorskiech, konstruowanych doraźne na potrzeby danej debaty.

Marian Przełęcki uważa, że metafora jest nieredukowalna do zbioru zdań Z1, Z2, Z3 itd. [Przełęcki 2002, s. 190]. Perelman nie zajmował się zagadnieniem przekładu metafory na zbiór wypowiedzi dosłownych, ale można przypuszczać, iż zgodziłby się z Przełęckim. W jego nowej retoryce trudno bowiem szukać miejsca dla wyrażenia metaforycznego rozumianego jako zamiennik zbioru zdań Z1, Z2, Z3. Użycie analogii, a tym samym metafory, wymaga zaistnienia pewnych okoliczności, które powodują, że wypowiedź dosłowna nie oddaje pełni znaczenia, jaki niesie ze sobą metafora.

W ten sposób obydwaj filozofowie sprzeciwiają się tezie Maxa Blacka, który twierdził, że „O czym można mówić tylko metaforycznie, o tym w ogólnie mówić nie należy" [zob. Black 1962, cytuję za Przełęcki 2002, s. 182].

O ile dla analogii można wskazać jasne kryteria, kiedy można ją stosować jako narzędzie argumentacji, o tyle w przypadku metafory jest to znacznie bardziej skomplikowane. Uznanie, że posługujemy się metaforami w filozofii, ponieważ brakuje nam dosłownych argumentów nie jest błędne. Wynika to z praktycznej funkcji języka. Parafrazując Wittgensteina można powiedzieć, że o czym nie można mówić dosłownie, o tym należy mówić metaforycznie.

\footnotetext{
${ }^{3}$ Przykładem takich działań są zorganizowane w roku 2014 przez Uniwersytet Waszyngtoński warsztaty poświęcone zagadnieniu metafory w argumentacji prawniczej, w który udział brali filozofowie prawa z całego świata, w tym i z Polski.
} 
Jednocześnie ta parafraza jest obostrzeniem. Perelman zdaje się uważać metaforę za jedno $\mathrm{z}$ ostatnich narzędzi, po jakie można sięgać $\mathrm{w}$ debacie filozoficznej. Wiąże się to $\mathrm{z}$ jednej strony $\mathrm{z}$ nieredukowalnością poznania filozoficznego do poznania naukowego, zaś z drugiej z praktycznym aspektem filozofii. Wyraźnie widać w tym miejscu, że wpływ na koncepcję belgijskiego myśliciela wywarł m.in. amerykański pragmatyzm, co znalazło swoje odzwierciedlenie w postrzeganiu metafory jako na narzędzia argumentacyjnego. Nie jest to bowiem wypowiedź bezwartościowa, która nie posiada sensu, jak chcieliby np. pozytywiści logiczni. Jednak, aby uniknąć bełkotu w toku argumentacji i zredukować ilość potencjalnych niepożądanych interpretacji należy niezwykle ostrożnie decydować się na jej użycie.

Ponieważ zdaniem Perelemana w filozofii nie możemy mówić o pojęciu prawdy, lecz o prawdopodobieństwie, metafora wielokrotnie będzie spełniała wymóg owego prawdopodobieństwa. Dzieje się tak, gdyż rozumienie nie jest dla niego procesem ograniczonym tylko do sfery języka. Wśród filozofów chętnie korzystających z analogii i metafor Perelman wymienia w pierwszej kolejności Platona i Plotyna, co wiąże się $\mathrm{z}$ ich poglądami na problemy metafizyczne. Podobnie jak on sam, ci dwaj antyczni myśliciele również odrzucali możliwość zredukowania poznania do języka.

Należy pamiętać przy tym, że Perelman tworzył swoją koncepcję nowej retoryki w czasach, gdy nie było jeszcze publikacji Models and metaphors Maxa Blacka i dlatego nie znajdziemy tam odniesień to tej koncepcji. Ponadto jego poglądy na metaforę i argument $\mathrm{z}$ analogii są ściśle związane zainteresowaniem logiką prawniczą, w której jednym z głównych celów jest perswazyjna i poznawcza wartość wyrażeń, a nie jak np. w logice nieformalnej Cohena, wartość heurystyczna i pedagogiczno-edukacyjna. Choć twierdził, że myśl filozoficzna ma przewagę nad prawniczą ze względu na poziom abstrakcyjnego myślenia, to jednak nie dostrzegał problematyczności użycia metafor w dyskursie filozoficznym. Był raczej skłonny uznawać, że swoistość argumentacji filozoficznej powoduje właśnie, iż użycie w jej toku metafor jest konsekwencją specyfiki samej dyscypliny.

\section{LOGIKA NIEFORMALNA DANIELA H. COHENA}

Współcześnie logika nieformalna kojarzona jest najczęściej z kręgiem amerykańskich i kanadyjskich filozofów skupionych wokół czasopisma Informal Logic $^{4}$. Wiąże się to określonym podejściem do tej gałęzi teorii argumentacji, gdyż w kręgu myślicieli skupionych wokół pisma założonego przez A. Blaira

\footnotetext{
${ }^{4}$ Obecnie czasopismo jest dostępne online pod adresem: www.informallogic.ca.
} 
oraz R. Johnsona dominuje przekonanie o społecznej odpowiedzialności filozofii. W przypadku amerykańsko-kanadyjskich logików często mówi się wręcz o ruchu logiki nieformalnej, który ma szkolić studentów i społeczeństwo w logicznej argumentacji ${ }^{5}$. Podobnie jak w przypadku nowej retoryki Perelman, tak i tu ethos, czyli pierwiastek etyczny mówcy odgrywa istotną rolę. Jednak zarówno w przypadku Blaira i Johnsona, jak i Cohena mamy do czynienia z teoriami skoncentrowanymi znacznie silniej na logosie.

Nie ulega wątpliwości, że wkład Daniela H. Cohena w rozwój teorii argumentacji jest znacznie skromniejszy od dokonań Chaima Perelmana, jednak w odróżnieniu od twórcy nowej retoryki, amerykański filozof zdecydował się poświęcić zagadnieniu metafory całą książkę, co już samo w sobie jest faktem godnym odnotowania.

W Arguments and metaphors in philosophy przedstawia on rolę metafory w dyskursie filozoficznym. Pisze on wręcz: „The language of philosophy is manifestly metaphorical" [Cohen 2004, s. 115]. W swojej publikacji pisze również o logice retoryki i retoryce logiki wskazując na miejsce metafory $\mathrm{w}$ dyskursie filozoficznym. Podobnie jak Perelmana, interesuje go zagadnienie argumentacji, ale z nieco innej perspektywy. Nie zajmuje się on jedynie perswazyjnym i eksplanacyjnym aspektem wyrażeń metaforycznych, lecz zwraca uwagę na szersze możliwości wykorzystania metafor w debacie filozoficznej.

\section{GŁÓWNE ZAŁOŻENIA LOGIKI NIEFORMALNEJ DANIELA H. COHENA}

W Arguments and Metaphors in Philosophy Cohen rozprawia się z użyciem metafor w ramach argumentacji filozoficznej, sięga przy tym jednak nie do tradycji arystotelesowskiej retoryki, lecz do postrzegania filozofii jako dialogu w duchu Sokratesa.

Cohen rozróżnia za Danielem J. O'Keefem Argument-1 (tu: argumentjako-dowód - np. dowód matematyczny) i Argument-2 (tu: argument-jakowojna - np. spór, sprzeczka) [tamże, s. 9]. Rozróżnienie to zostało zaproponowane przez O'Keefa w artykule zatytułowanym Two Concepts Of Argument [O'Keefe 1977, s. 121-128].

Należy w tym miejscy zastrzec, że podział ten wynika z wieloznaczności słowa ,argument” w języku angielskim. Zdaniem Cohena w większości przypadków mamy do czynienia $\mathrm{z}$ drugim znaczeniem terminu argument, jest to zasada ogólna, która dotyczy wszelkich form komunikacji.

\footnotetext{
${ }^{5}$ Wymowny jest tytuł najważniejszej książki Blaira i Johnsona, brzmi on Logical Self-Defence.
} 
Zarówno w trakcie dyskusji prowadzonej na żywo, jak i w eseju naukowym filozofowie zazwyczaj posługują się terminem ,,argument” w znaczeniu Argument-1. Jego zdaniem w drugim przypadku trudno bowiem o zagwarantowanie racjonalnych ram debaty, jeżeli celem nadrzędnym naukowców i filozofów będzie jedynie zwycięstwo. Można powiedzieć, że w takiej sytuacji mielibyśmy do czynienia erystyką, a nie z racjonalną argumentacją.

Oczywiście Argument-1 nie może zostać ograniczony do dowodu matematycznego. W obszarze etyki lub metafizyki może to być dowolne twierdzenie oparte na racjonalnych założeniach, które wygłaszane jest dla dowiedzenia lub poparcia głównej tezy.

W języku polskim pojawia się jeszcze trzecie znaczenie, otóż argument możemy rozumieć jako przesłankę, jednak temu zagadnieniu Cohen nie poświęca miejsca.

Pojawia się w związku z tym pytanie. Czy metafora użyta w ramach filozoficznej argumentacji jest czymś innym niż tylko figurą stylistyczną?

Cohen podkreśla, że w argumentacji perswazja nie odgrywa jedynej, czy też kluczowej roli. Równie istotnym jest zrozumienie, poznanie, czy też potwierdzenie pewnych tez. Dlatego proponuje on zwrócić większą uwagę na tzw. „strategię wyjścia” - sposoby zakończenia danej wymiany argumentów [zob. Cohen, dz. cyt., s. 15]. To ona pozwala ocenić, czy mamy do czynienia $z$ debatą filozoficzną, której celem jest uzgodnienie pewnych kwestii, czy też zwycięstwo jednego $\mathrm{z}$ dyskutantów.

\section{METAFORA W LOGICE NIEFORMALNEJ DANIELA H. COHENA}

Jak już wspomniałem, Cohen reprezentuje typowe dla filozofów skupionych wokół Blaira i Johnsona zatroskanie o pedagogiczno-edukacyjną rolę logiki nieformalnej. Dlatego też skupia się na innym aspekcie wyrażeń metaforycznych, który wymyka się np. nowej retoryce.

W odróżnieniu od Perelmana nie redukuje on roli metafory w argumentacji, do środka wyrażania tego, czego nie da się powiedzieć w sposób dosłowny. Ta rola jest przez Cohena dostrzegana, ale nie stanowi dla niego problemu godnego zainteresowania. Jako filozofa metafora interesuje go głównie z przyczyn poznawczo-heurystycznych.

Zdaniem Cohena metafora ma głównie wartość:

- heurystyczną,

- poznawczą,

- edukacyjno/szkoleniową. 
To właśnie wartość edukacyjno-szkoleniowa metafory jest kluczową w procesie rozwoju filozoficznego. Uważa on, że głównym zadaniem filozofii, w tym logiki nieformalnej, jest nie tylko uczenie poprawnej, racjonalnej argumentacji, ale również umiejętność spojrzenia na pewne problemy z nowej perspektywy. Widać zatem, że nadrzędnym powodem, który motywuje Cohena do przyjrzenia się metaforze używanej $w$ ramach filozoficznej argumentacji jest jej wartość poznawcza, ale rozumiana na dwa sposoby.

Dla lepszego zrozumienia jego poglądów proponuję podział jego refleksji nt. metafory na poznanie P1 i P2. Choć sam autor nie stosuje tego podziału, to w świetle jego koncepcji wydaje się on zasadny, aby klarownie pokazać różnicę pomiędzy celem zastosowania metafory w procesie poznawczym.

Poznanie P1 jakiego dostarcza metafora $\mathrm{w}$ filozofii jest poznaniem typowym dla całej filozofii. Przykładem takim jest metafora Pascala „człowieka jako trzciny". Jest to powszechnie znana w filozofii metafora, która pozwala na przedstawienie m.in. kruchości życia człowieka w obliczu wszechmocy Boga. Stosowana jest ona, aby przekonać audytorium do poglądów głoszonych przez danego filozofa. Jej zastosowanie ma charakter nie tylko dla samego autora, ale również dla tych, którzy są gotowi wejść $\mathrm{z}$ nim $\mathrm{w}$ dyskusję. Metafora ma tu do spełnienia funkcję perswazyjną - ma pomóc autorowi w zjednaniu audytorium lub przynajmniej przygotować płaszczyznę do debaty.

Poznanie P2 jakiego dostarcza użycie metafory w filozofii można określić jako poznanie indywidualne. Celem konstruowania metafory jest przede wszystkim wartość heurystyczno-edukacyjna młodych adeptów filozofii, których zadaniem jest trenowanie krytycznego myślenia. W takim przypadku nie chodzi głównie o to, aby przekonać audytorium, ale aby pedagog zachęcił uczniów lub studentów do postrzegania danego zjawiska w nowy, niestandardowy sposób. Dlatego w koncepcji Cohena mniej istotny jest aspekt perswazyjny metafory, czy też jej wartość komunikacyjna, a ważniejszy jest aspekt poznawczo-szkoleniowy. Uważa on, że metafory są nieodłącznym elementem filozofii i dlatego proponuje, aby całą historię filozofii postrzegać jako „produkcję wielkich metafor” [tamże s. 142].

Przykładem takiej wielkiej metafory jest „łańcuch bytów” św. Augustyna. Jest to przykład, do którego większość z czytelników przywykła, który zwykle jest traktowany niemal dosłownie, a to dlatego, że z jednej strony dobrze oddaje zagadnienie hierarchii bytów, a z drugiej idealnie obrazuje to zagadnienie. Pozwala nie tylko wskazać na istotne elementy tej koncepcji, ale również dobrze ją zobrazować poprzez wykorzystanie pożądanych konotacji. 
Cohen dostrzega pokrewieństwo metafor i kontrfaktycznych eksperymentów myślowych:

Tak jak metafory, kontrfaktyczne eksperymenty myślowe są integralną częścią filozoficznych projektów starających się nadać sens naszemu światu. Jednak proponowanie metafor i wyobrażanie sobie alternatywnych możliwości są bardzo różnymi poczynaniami intelektualnymi. W pierwszym przypadku chodzi o spojrzenie na świat w nowym świetle, w drugi o wyobrażenie sobie kompletnego innego świata [tamże s. 4 (tłumaczenie własne)].

Podkreśla, że postrzegając świat przez pryzmat metafory, nie postrzegamy innego świata [tamże, s. 200], lecz zaczynamy inaczej patrzeć na znany nam świat. Jednocześnie uważa, że metafora dobrze wkomponowana $\mathrm{w}$ argumentację może przyczynić się do tego, iż na trwałe zmienimy sposób postrzegania rzeczywistości, a nie jedynie na krótką chwilę - jak ma to miejsce, np. w przypadku metafor stosowanych $\mathrm{w}$ debacie publicznej w celach doraźnych.

O tym czy dane wyrażenie powinno być rozpatrywane jako metaforyczne, czy jako dosłowne dowiadujemy się z kontekstu wypowiedzi. Cohen przytacza słynny przykład Tarskiego Snow is white. Uważa, że zwykle rozumiemy to zdanie jako dosłowne (abstrahuje tu od ujęcia tego zdania na metapoziomie), ale $\mathrm{w}$ pewnych okolicznościach może być to wyrażenie metaforyczne. Jako przykład podaje wypowiedzenie tego samego zdania w chwili, gdy na stole znajduje się kokaina [tamże, s. 8]. Jest oczywistym, że osoba wypowiadająca takie zdanie ma na myśli kolor narkotyku, a nie zjawisko pogodowe.

Dalej zauważa, że czasami odczytujemy całe dzieła jako wyrażenia metaforyczne, czego przykładem jest Biblia, w której wiele opowieści jest dziś traktowana metaforycznie. $\mathrm{Na}$ interpretację danych wypowiedzi jako metaforycznych ma bowiem wpływ kontekst kulturowy, a ten zmienia się wraz $z$ upływem czasu. Przed metaforą nie ma bowiem ograniczeń a priori, dzięki czemu możemy czerpać z niej wartość heurystyczną. Natomiast jej interpretacja jest już ograniczona kryterium a posteriori, a jest nim skuteczność. Nie sposób apriorycznie rozstrzygać, czy dana metafora będzie skuteczna, ale można to rozstrzygnąć aposteriorycznie.

Cohen stwierdza, że nie ma jednej filozoficznej metody, jednego stylu czy celu i dlatego pewne metody mogą być nieadekwatne dla gałęzi filozofii, dla których nie zostały skonstruowane. Tak jak np. Thomas Kuhn twierdzi, że łączy je tylko jedno - potrzeba osądzenia przebiegu argumentacji. Zwraca on uwage na to, że argumenty nie powinny być rozpatrywane w oderwaniu od paradygmatu, nurtu czy danej szkoły filozoficznej. 
W kluczowym rozdziale Arguments and metaphors in philosophy, zatytułowanym Metaphors as Arguments And Arguments as Metaphors, Cohen wymienienia cztery najważniejsze relacje, mogące zachodzić między metaforą i argumentacją:

1) metafory, których używamy mówiąc o argumentach;

2) rola metafor $w$ argumentacji (np. doskonale objaśniają pewne zagadnienia filozoficzne, wzbogacają argumenty stylistycznie i estetycznie);

3) sposoby, w jaki posługujemy się metaforami w toku argumentacji;

4) możliwość metaforycznego odczytania argumentów [tamże, s. 8].

Z pierwszym przypadkiem mamy do czynienia, gdy postrzegamy argumentację jako wojnę. Mówimy wtedy o tym, że mamy silne lub mocne argumenty. Jesteśmy przekonani, co do możliwości zwycięstwa w danej dyskusji. Stosowanie tej powszechnej metafory powoduje, że wymianę zdań zaczynamy traktować jako pole bitwy, na którym ścieramy się z przeciwnikiem.

Można mówić tu o całej puli wyrażeń metaforycznych opartych na argumentacji rozumianej jako wojna. Mówimy np. o przeciwniku w dyskusji, a rzadziej o dyskutancie, uważamy, że wygrywamy lub przegrywamy daną debatę, a nie deliberujemy.

Metafory wojenne są najpowszechniejszymi, gdy myślimy o argumentacji w języku potocznym. Również o debatach naukowych myślimy zwykle w kategoriach ukształtowanych przez konotacje militarne. Ponieważ metafora argumentacji-jako-wojny jest tak silnie osadzona w naszym myśleniu o niemal każdej dyskusji, autor Arguments and metaphors in philosophy uważa, że jest to jedna ze źródłowych metafor w naszej kulturze [tamże, s. 198]. Wydaje się to twierdzeniem niekontrowersyjnym.

$\mathrm{Z}$ drugim przypadkiem mamy do czynienia, gdy posługujemy się metaforami, aby zilustrować pewne zagadnienia. W takich sytuacjach metafora pełni funkcję dodatkowej przesłanki, która ma wzmocnić główny argument lub przybliżyć nieznane zagadnienie poprzez wykorzystanie znanych terminów. Mówca posługujący się danym wyrażeniem metaforycznym stosuje je w takiej sytuacji $\mathrm{w}$ celach eksplanacyjnych i stosując metaforę chce uniknąc problemów w dowodzeniu swojej tezy. Takie podejście jest zbliżone do standardowego użycia argumentu $\mathrm{z}$ analogii. $\mathrm{W}$ ten sposób traktowana jest metafora w nowej retoryce Chaima Perelmana.

Należy w tym miejscu nadmienić, że metafora może uczynić to, co znane nieznanym pokazując problematyczność poglądów, które uchodzą za powszechne wśród danego audytorium. W takiej sytuacji na pierwszy plan 
wybija się rola edukacyjna metafor. Ich zadaniem jest przybliżenie pewnych problemów filozoficznych lub skłonienie audytorium do tego, aby zaczęło myśleć krytycznie na temat rozwiązania jakiegoś powszechnie akceptowanego zagadnienia.

$\mathrm{Z}$ trzecim przypadkiem mamy do czynienia, gdy $w$ toku argumentacji metafory stają się jej integralnym elementem. Nie postrzegamy ich wówczas jako elementów stylu lub sposobów na zwiększenie eksplanacyjnego aspektu wywodu, lecz jako pełnoprawne, choć słabsze, odmiany argumentów. Podobnie jak w przypadku Perelmana, Cohen upatruje takiego zastosowania metafor głównie w argumentacji z obszaru metafizyki.

Sytuacja ta dotyczy zwykle metafor źródłowych lub takich, które w danej kulturze są już na tyle zakorzenione, że audytorium postrzega je jako osobne wypowiedzi argumentacyjne. Często przez samego mówcę są one stosowane niemal odruchowo. Przykładem tak rozumianej metafory może być człowiek jako trzcina, o której pisał Pascal. Inną taką metaforą jest np. wyrażenie „Ryszard lwie serce”. Osoba wypowiadająca to sformułowanie nie twierdzi bynajmniej, że:

1) Ryszard jest sercem;

2) Ryszard jest lwim sercem;

3) Ryszard posiada lwi organ.

Kompetentny użytkownik języka będzie wiedział, że konotacje, które przypisuje się lwu zostają przeniesione na postać historycznego króla Ryszarda. Wśród tych konotacji pierwszą z nich jest królewska godność - lew konotuje króla dżungli, co zbliża go do postaci króla Anglii. Drugą zaś jest konotowanie postaci lwa z męstwem, a tym samym jego organu $\mathrm{z}$ odwagą. Wiedza na temat metaforycznego znaczenia tego przydomku jest na tyle powszechna, że zwykle nie zauważamy jego metaforyczności.

Niekonkluzywność metafor, nawet silnie zakorzenionych w danej kulturze, skutkuje dużą otwartością na interpretację. Oto oponent osoby posługującej się daną metaforą może zinterpretować ją w sposób niezgodny z zamysłem mówcy. Sytuacja taka jest tym bardziej prawdopodobna, im bardzie oryginalne jest dane wyrażenie.

Z czwartym przypadkiem spotykamy się, gdy same argumenty zaczynamy odczytywać jako wyrażenia metaforyczne. Cohen ma w tym miejscu na myśli sytuację, w której dane wyrażenie dosłowne zaczynamy traktować w sposób niedosłowny. Zakłada się wówczas, że wyrażenie dosłowne jest czymś więcej niż tylko twierdzeniem przytoczonym w ramach danej mowy. Zwykle dochodzi do takiej sytuacji, gdy kontekst w jakim pojawia się dana 
wypowiedź odbiega od standardowego kontekstu. Wówczas to nie nietypowe zestawienie słów leży u podstawy uznania danego wyrażenia za metaforyczne, lecz kontekst jego użycia. Takie podejście jest poznawczo wartościowe, gdy samą sztukę argumentacji postrzegamy jako dialog lub wojnę. Może być bowiem tak, że pod postacią standardowej wymiany zdań kryje się jakiś ukryty problem (np. chęć zdominowania jednego dyskutanta przez drugiego). Wówczas właściwym znaczeniem danej wypowiedzi jest to, które leży poza jej dosłownym odczytaniem.

Cohen przytacza przykład pary kochanków sprzeczających się o film. Jeżeli dana wymiana zdań przeradza się w agresywna kłótnię każdy kompetentny użytkownik języka będzie miał podstawy do tego, aby uznać, że całość wypowiedzi kochanków ma znaczenie metaforyczne, a problemem nie jest film.

Dalej Cohen zauważa, że podobnie jak metafory, tak i argumenty mają możliwość kształtowania nowego oblicza problemu w oczach audytorium. Trzeba jednak podkreślić, iż nie poświęca on zbyt wiele miejsca roli audytorium $\mathrm{w}$ procesie argumentacji. Jego teoria koncentruje się głównie na logosie i ethosie, pozostawiając pathos kwestią domysłu.

$\mathrm{Z}$ tego powodu jego koncepcji można zarzucić jednostronny model komunikacyjny. Choć nie zakłada on, że każdy, nawet najbardziej racjonalny argument zostanie przyjęty przez racjonalne audytorium, to jednak zdaje się być zdania, iż zadaniem logiki nieformalnej nie jest rozważanie kwestii związanych $\mathrm{z}$ audytorium. Przedmiotem dociekań logicznych jest tylko argument. Milcząco zdaje się powstrzymywać od wkraczania w obszar pathosu i psychologii. Taka postawa jest godna odnotowania, gdyż ostatnimi czasy niektórzy myśliciele z kręgu amerykańskiej i kanadyjskiej logiki nieformalnej mając coraz częściej tendencję do analizowania wszelkich argumentów, w tym i przekazów graficznych, dodając komponentę psychologiczną. Stanowisko takie może być szkodliwe, gdyż powoduje zacieranie granicy między logiką nieformalną, a np. psychologią czy semiotyką kultury.

Podsumowując koncepcję Daniela H. Cohena należy stwierdzić, że jest ona znacznie bardziej rozbudowana od propozycji Chaima Perelmana. Metafora nie jest dla Cohena jedynie środkiem stylistycznym lub odmianą argumentu $\mathrm{z}$ analogii, lecz potężnym narzędziem stosowanym niemal cały czas w filozoficznej argumentacji tam, gdzie chcemy zwrócić uwagę na dany problem i podkreślić aspekt heurystyczny. Jest zatem narzędziem służącym do ćwiczenia umiejętności heurystycznych adeptów filozofii, a następnie narzędziem poznawczym bardziej zaawansowanych myślicieli.

Jednocześnie widać, że kwestia relacji metafory i argumentacji jest dla Cohena dużo bardziej złożona niż dla wielu autorów, którzy traktują ją jako 
odmianę argumentu $\mathrm{z}$ analogii. Uważa on, że w ramach teorii argumentacji logika nieformalna powinna zwracać uwagę na to, iż nie tylko poszczególne wypowiedzi są wypowiedziami metaforycznymi. Równie ważnym jest, aby dostrzegać, że całe zdania lub wymiany argumentów w danej sytuacji mogą mieć znaczenie metaforyczne.

\section{SŁOWO KOŃCOWE}

Nie da się ukryć, że choć wkład Perelmana w rozwój tego, co zwykło się nazywać teorią argumentacji jest znacznie większy, to jednak w kwestiach związanych $\mathrm{z}$ teorią metafory stosowaną $\mathrm{w}$ celach argumentacyjnych Cohen wiedzie prym. Poniżej, w formie skrótu przedstawiam punkty wspólne i rozbieżne w myśli obydwu filozofów.

Koncepcje Perelmana i Cohena łączy:

- koncentracja na logosie w ramach argumentacji,

- przekonanie, że w filozofii mówimy o przekonaniach, a nie o prawdzie,

- potraktowanie metafory jako narzędzia argumentacyjnego pełnoprawnego w dyskursie filozoficznym,

- przeświadczenie, że nieredukowalność poznania filozoficznego do poznania naukowego uzasadnia stosowanie metafor,

- inspiracje filozofią amerykańskiego pragmatyzmu.

Różni je natomiast w sposób widoczny sposób konstruowania własnych teorii. Perelman tworzy całościową teorię argumentacji opartą głównie o logikę prawniczą, którą określa mianem nowej retoryki. Jest to systematyczny wykład, będący traktatem z zakresu logiki retoryki, w którym wszystkie zagadnienia zostają systematycznie wyłożone niczym w porządnym podręczniku logiki. Tymczasem propozycja Cohena przywodzi na myśl esej filozoficzny, w którym autor przedstawia swoje poglądy na temat argumentacji i roli metafory w filozofii.

Zarówno nowa retoryka Perelmana, jak i logika nieformalna Cohena wpisują się w te odmiany retoryk, czy też teorii argumentacji, które koncentrują się na logosie, a nie pathosie lub ethosie mówcy. Przy czym każdy z autorów dostrzega istotną rolę ethosu, który wspiera logos. Łączy ich również znikome zainteresowanie aspektem pathosu $\mathrm{w}$ ramach debaty publicznej.

Podjęte w niniejszym tekście zagadnienie miało na celu pokazanie, jak można postrzegać rolę metafory w argumentacji filozoficznej, nie ograniczając się jedynie do przypisywania jej funkcji estetycznej czy perswazyjnej. Przed- 
stawione koncepcje nie wyczerpują możliwych interpretacji związków metafor i współczesnych teorii argumentacji, stanowią zaledwie dwa przykłady tego, jak bardzo złożone może być podejście do tego problemu.

\section{BIBLIOGRAFIA}

Black, M. (1962), Models and Metaphors. Cornell University Press.

Cohen, D. (2004), Arguments and Metaphors in Philosophy. Maryland, University Press of America.

Kleszcz, R. (2005), Teoria argumentacji, filozofia, logika. Uwagi o teorii Chaima Perelmana. „Forum Artis Rhetoricae”, s. 5-6.

Meyer, M. (2010), Historia retoryki od Greków do dziś, tłum. Z. Baran. Wydawnictwo Aletheia.

O'Keefe, D. J. (1977), Two Concepts of Argument. „The Journal Of The Forensic Association”, nr 3, s. 121-128.

Perelman, C., Olbrechts-Tyteca, L. (1958,) Traite de l'argumentation. Presses Universitaires de France.

Perelman, C. (1984), Logikaa prawnicza. Nowa retoryka, tłum. T. Pajor. Państwowe Wydawnictwo Naukowe.

Przełęcki, M. (2002), O metaforze w filozofii, [w:] O rozumności i dobroci. Wydawnictwo Semper.

Szymanek, K. (2001), Sztuka argumentacji - słownik terminologiczny. Państwowe Wydawnictwo Naukowe.

\section{METAPHOR IN CHAIM PERLEMAN'S NEW RHETORIC AND \\ DANIEL H. COHEN'S INFORMAL LOGIC}

(Abstract)

In the paper I compare two points of view on metaphor as a tool of argumentation: the approach of Chaim Perelman and the one of Daniel H. Cohen. Both authors discussed the problem of metaphor from the point of view of rhetoric, theory of argumentation and philosophy of language, and in consequence they conceived metaphor as an argumentative tool. The paper is divided in two main parts. In the first part I discuss Chaim Perleman's new rhetoric and his conception of using metaphors. The second part is about Daniel H. Cohen's informal logic and his proposal of metaphor use in argumentation.

\section{KEYWORDS}

Argumentation, metaphor, new rhetoric, informal logic, theory of metaphor. 